\title{
Assessment of the EU Countries' Economic Security based on the Composite Indicators
}

\author{
OLENA KHADZHYNOVA
}

Sustainable Innovations Laboratory,

Mykolas Romeris University, Ateities g. 20, 08303, Vilnius

LITHUANIA

\section{ŽANETA SIMANAVIČIENĖ}

Business Innovation Laboratory, Mykolas Romeris University, Ateities g. 20, 08303, Vilnius

$$
\text { LITHUANIA }
$$

\section{OLEKSIY MINTS}

Department of Finance and Banking,

Educational Research Institute of Economics and Management,

SHEI "Pryazovskyi State Technical University", vul. Universytetska 7, 87500, Mariupol

UKRAINE

PAVLO BURAK

Faculty of Public Governance and Business, Mykolas Romeris University,

Ateities g. 20, 08303, Vilnius

LITHUANIA

\section{VALENTYNA KHACHATRIAN}

Department Economy and International Relations,

Vinnytsa Institute of Trade and Economics of Kyiv National University of Trade and Economics,

Soborna St, 87, 21050, Vinnytsia

UKRAINE

\begin{abstract}
The authors propose an integral indicator of the economic security of a country, based on a study of economic, social, political and environmental indicators of security of 28 European Union countries. The study used panel regression methods, correlation analysis, nonlinear approximation, graphical methods. The research results make it possible to explain up to $58 \%$ of the variations in the studied indicators. The calculated values of the integral indicator of economic security correspond to empirical data. The indicator proposed by authors comprehensively characterizes the current state of the country's economic security in the economic, social, political and environmental spheres. This indicator makes it possible to determine the level and disproportions of the country's development and can become the basis for the formation of directions for ensuring its economic security.
\end{abstract}

Key-Words: - economic security, composite indicators, indices, economic development, statistical analysis, panel regression

Received: May 21, 2021. Revised: January 12, 2022. Accepted: February 13, 2022. Published: February 23, 2022. 


\section{Introduction}

The analysis of real processes and comprehension of domestic and foreign experience make it possible to single out three elements of economic security:

1. Economic independence in the modern world economy is not absolute. It means the possibility of state control over national resources, the achievement of such a level of production, efficiency and quality of products that ensure the competitiveness of the state, allowing it to participate on an equal footing in the world trade [1].

2. The stability and sustainability of the national economy is determined by the degree of protection of property in all its forms, the creation of reliable conditions and guarantees for entrepreneurial activity, and the containment of factors capable of destabilizing the situation [2].

3 . The ability for self-development and progress. Creation of a favorable climate for investment and innovation, constant modernization of production, raising the professional educational level of workers are becoming necessary and indispensable conditions for the sustainability and selfpreservation of the economy [3].

Taking into account the conflicting research results, the lack of consensus among scientists regarding the set of economic security factors and the degree of their influence on the efficiency of the economy, the choice of methods and tools for folding individual indicators into an integral assessment - further research is needed on this topic.

\section{Problem Formulation}

Nowadays different scientists propose various methods and approaches to assessing economic security [4-5]. They can be based on an indicative analysis, analysis of various kinds of quantitative and qualitative indicators, the use of integral indicators and indices. Approaches to assessing and analyzing economic security differ from country to country, making it difficult to compare countries, because of this there is still no international index of the economic security of countries. To assess economic security, the calculation of composite indicators of sustainable development of countries is widely used. The methods for assessing economic security that are used in international practice have a number of application restrictions. Thus, our research is aimed at further developing a methodology for assessing and analyzing the economic security of countries.
According to the author, one of the key issues in assessing economic security is the choice of the basis for the assessment, namely a set of indicators that take into account all the main threats to the economic security of the country.

A large number of scientists use complex indices as indicators of economic security rather than individual indicators. One of the first scholars to use a comprehensive assessment of economic security was J. David Singer. He based his research on The Composite Index of National Capability (CINC) [6]. It uses six different components to represent economic, demographic and military strength. Today, many scientists use their research CINC and it remains one of the best known and most widely used methods for measuring national potential.

Osberg L. and Sharp A. show in their study that it is possible to build a composite index of economic security at the state level and use it in both developed and developing countries [7].

Mourougane A. and Roma M. study the impact of the Industrial Confidence Indicator (ICI) and the Economic Sentiment Indicator (ESI) on GDP growth in the European Union [8].

In turn, $\mathrm{H}$. Poirson in his work uses the following components of the indices as indicators of economic security: political rights, civil liberties, racial, ethnic and nationality tensions, rule of law, bureaucracy quality, corruption, risk of expropriation, population growth, secondary school enrollment rate and number of years open to international trade and studies their impact on gpd per capita growth [9].

The impact of economic performance on a country's economic security is described in RAND Europe commissioned by the Research and Documentation Center (WODC) to study the relationship between economic performance and national security, as well as to characterize and assess economic performance [10].

It should be noted that most of the listed above studies were carried out quite a long time ago. At the same time, economic relations are constantly developing and are supplemented by new factors. This necessitates updating the set of indicators of economic security, taking into account the modern information base and economic trends.

The purpose of the article is to substantiate the integral indicators of the economic security of the EU countries and assess their impact on the efficiency of economic development.

Research methods and information used. The initial data for the analysis are information from open sources on macroeconomic indicators, as well as complex development indices of the EU countries. Methods for standardizing indicators were used to 
fill the information base. During the research, methods of statistical analysis, aggregation, and data clustering were used.

\section{Problem Solution}

Currently, the criterion of the economic security of the state is the degree of compliance of the economic policy pursued with the chosen strategy for the development of the national economy, as well as the level of trust in it both on the part of the population and international organizations.

This criterion should be characterized by the integral system of indicators of economic security, which reflects certain particular aspects of this problem. In this regard, it is proposed to single out several groups of indicators of economic security.

Our research is aimed at developing a methodology, assessment and analysis of the economic security of countries. The analysis is based on a system of independent, representative indicators. Assessment indicators should be available for analysis and correct comparison (presented in the annual official statistics for countries), which will make it possible to obtain both a generalized assessment of economic security by components (economic, political, etc.), and by individual indicators that reflect existing security threats; and will allow comparing countries in terms of the level of economic security and the effectiveness of government actions in order to support it to ensure the sustainable development of countries. Economic security is considered by the author in terms of ensuring sustainable development of the country, namely, balanced economic growth, which is accompanied by the solution of many social, political, economic and environmental problems.

Further solution of the problem is logically divided into next stages. - data preparing, researching data structure and Modeling.

\subsection{Data Preparing}

The information base of the study is data on the values of the indices of economic, social, political, environmental development as well as GDP, GDP per capita and its growth of 28 European countries for the period from 2010 to 2019. When choosing dependent variables, the authors proceeded from the fact that the country's economic security is manifested in the sustainability of the growth of the main indicators of its economic development. This indicators in many researches are in one way or another related to the volume of gross domestic product (GDP) $[4,5,8]$. Usually, indicators such as total GDP and GDP per capita are distinguished. At the same time, the use of absolute indicators in a generalizing study is inappropriate, since in different countries they can differ significantly. For example, Malta's GDP in 2019 was $€ 13.5$ billion, while Germany's GDP was $€ 3.449$ billion. Even using such an indicator as GDP per capita is not entirely correct. In 2019, in the EU, it ranged from 6,840 euros (Bulgaria) to 83,640 euros (Luxembourg). At the same time, the indicators of relative GDP growth in comparison with the previous period seem to be more preferable for use, since, firstly, they do not have a large spread for different countries, and secondly, they better reflect the dynamics of the country's development. Thus, as the main dependent variables, authors chose indicators of relative GDP growth and relative growth of GDP per capita.

In addition, as studies show, macroeconomic processes are rather slow and inertial. Therefore, the results in the form of changes in GDP growth rates may appear with some delay [11]. This is why it is necessary to include in the dataset the output variables taken with a lag in relation to the input ones. As part of this study, authors additionally analyzed the dependent variables taken with a 1year delay.

Choosing the right sub-indicator system is the key to obtaining an objective assessment of it. This scorecard should take into account all threats to economic security. All indicators used must be independent, comparable and representative. Author proposes to base the assessment of the level of economic security of the country on a hierarchically constructed system of indicators, which includes a compiled indicator formed on the basis of subindicators grouped by components. As described earlier, the formation of a system of subindicators for assessing the economic security of a country should be carried out in accordance with the principles of representativeness, reliability and availability of information. In order to form a system of indicators for assessing the level of economic security of a country, authors analyzed the composition of subindicators used by well-known international indices and ratings: Global Competitiveness Index [12]; Index of Economic Freedom [13]; Fragile states index [14]; Globalization Index KOF [15]; Human Development Index [16]; Doing business [17]; Democracy index [18]; Corruption Perceptions Index [19]; Prosperity Index Legatum [20] and the Environmental Performance Index [21]. 
The set of indicators selected for further research of their representativeness and impact on economic security is given in Table 1.

Table 1. The system of indicators to research the economic security of the EU countries

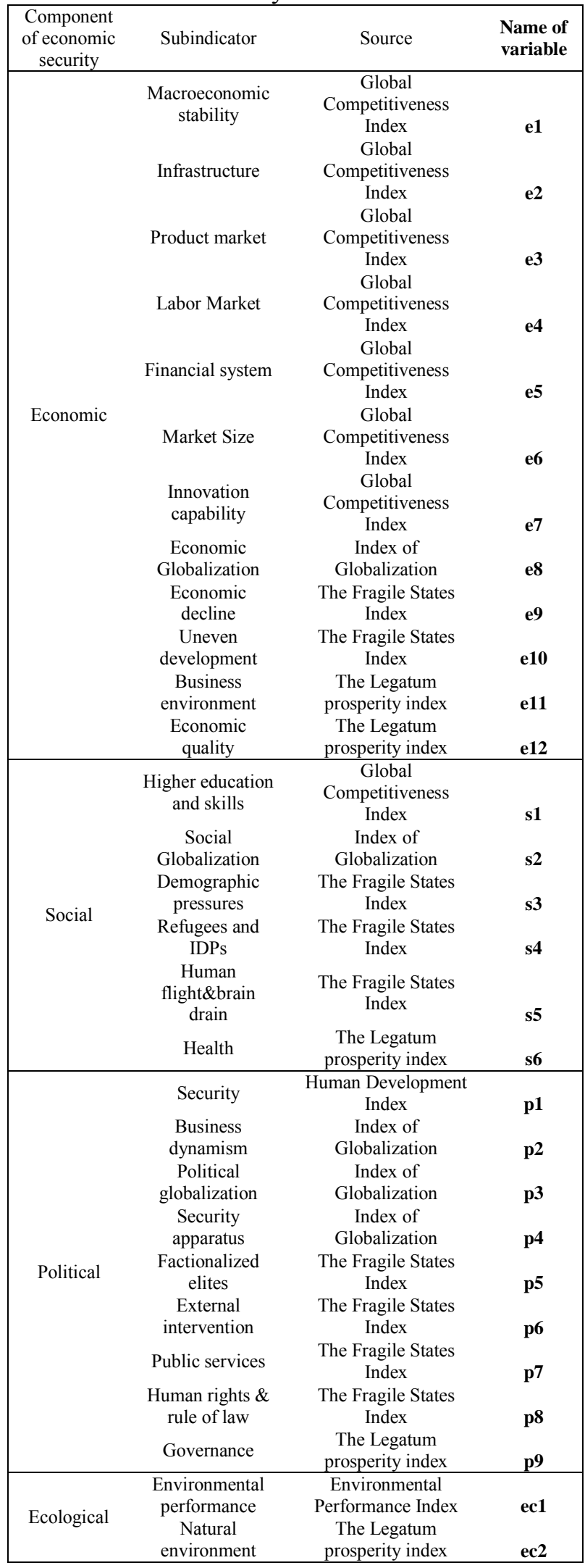

\section{Source: Authors`development}

To ensure the correctness of further statistical calculations with the raw initial data, the following actions were performed:

1. Bringing to a single scale.

2. Identification of distortions.

3. Normalization.

As a result of steps 1-3, all input data is reduced to the range $[0 ; 1]$, in which it is located according to the principle "more = better". 4 .

4.Analysis of cross-correlation in data.

The analysis showed the absence of completely identical indicators. But at the same time, some variables are quite strongly related to others, and, therefore, contain little additional information and can potentially be excluded from the input data sample. Thus, the indicators e7 (Innovation capability) and p2 (Business dynamism) have a correlation of more than 0.8 with 8 other indicators, as well as a correlation of 0.9287 with each other.

5. Data aggregation.

Since the input data have a large dimension (29 independent variables) for further research, it is advisable to aggregate them to reduce the dimension.

It should be noted that the use of compiled indicators to study multidimensional phenomena (including economic security) is already widely used in various areas of modern research [22-28]. Many scientific works confirm the advisability of using this approach, since the compiled indicators allow to obtain correctly interpreted results with the correct development of these indices, which should be based on: a clear theoretical understanding of the phenomenon under study, a reasonable choice of the group subindicators and testing them for multicollinearity, indicator normalization, and correct aggregation of subindicators [28-32]. The most widely used aggregation method is additive [23, 29].

In this study, to aggregate data the authors used averaging values that have the same direction of influence on the result, in the context of each group of independent variables. However, the selection of indicators that should be averaged can only be performed after examining the data structure and is therefore described in more detail in subsection 3.3.

\subsection{Researching Data Structure}

The studied data has a panel structure, it contains spatial (country) and temporal (year of observation) characteristics that display statistical information about the same set of objects over a number of consecutive periods of time. 
To choose the best method for analyzing such data, it is necessary to test the hypothesis about the influence of the panel data structure on the dependent variables, as well as the nature of such influence.

To assess the influence of the spatial data structure on the dependent variables, we will use the between estimate (Fig. 1). In this case, only one output variable is evaluated, since the structure of the data itself is the same for all models.

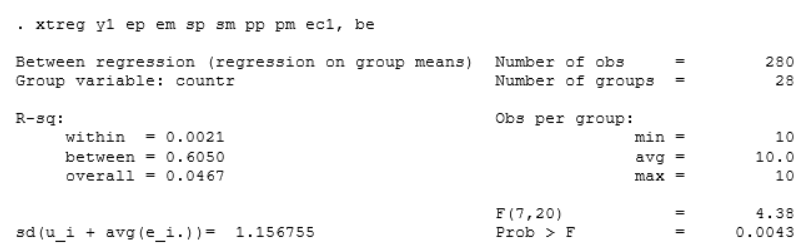

Fig. 1: Parameters of between regression

Source: Authors`own calculations in STATA

When analyzing the results of this regression model, the main indicators are between $=0.6050$ and within $=0.0021$.

In this case, the R-sq between value reflects the quality of the regression fit and is large enough $(0.6050)$, i.e. the change in the average over time for each country has a more significant impact on each variable than the temporal fluctuations of these indicators relative to the average.

Among the panel regression models, there are models with random effects and fixed effects [33].

Random effects models are simpler, but only work well if the data that is being analyzed is part of a larger population.

Fixed-effect models allow to take into account individual spatial characteristics of the data, but are more complex to implement and use.

Next authors need to compare the fixed effects model with the end-to-end regression model using Wald's test. At the same time, the hypothesis about the equality of all individual effects to zero is tested (Fig. 2 - Fig. 3).

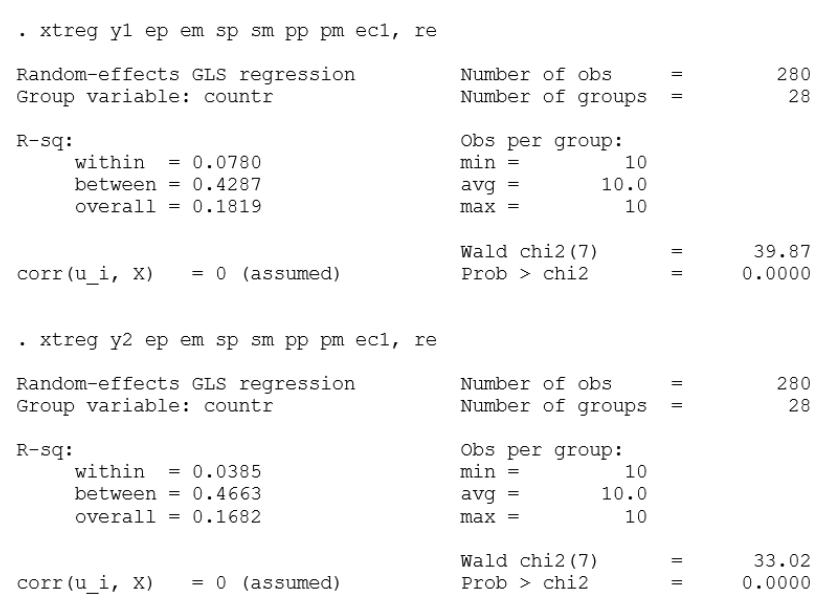

Fig. 2: Parameters of random effects panel regression

Source: Authors`own calculations in STATA

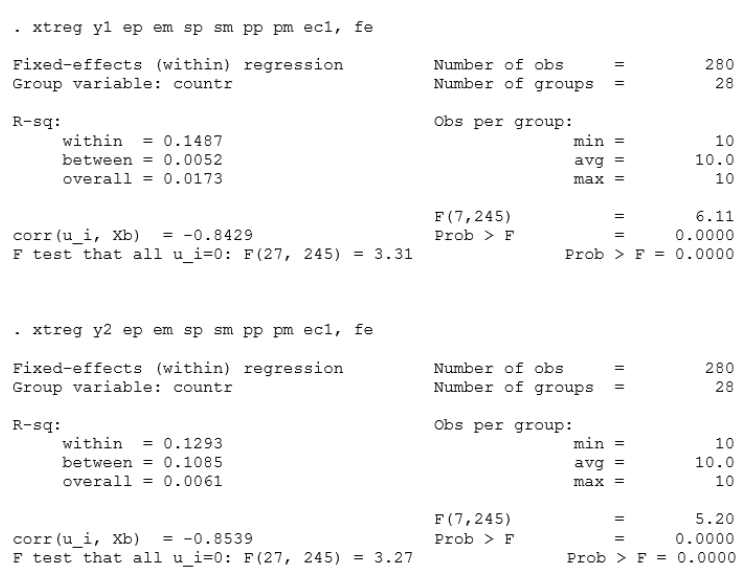

Fig. 3: Parameters of fixed effects panel regression Source: Authors`own calculations in STATA

Since in all the constructed models with fixed effects Prob $>F=0.0000$, the hypothesis is rejected, therefore, the model with fixed effects better describes the available data.

Let us evaluate the comparative efficiency of models with random and fixed effects using the Hausman test (Fig. 4) [34].

- hausman y1_fe y1_re

Test: Ho: difference in coefficients not systematic

$$
\begin{aligned}
& \begin{aligned}
\operatorname{chi2}(7) & =(\mathrm{b}-\mathrm{B})^{\prime}\left[\left(\mathrm{V}_{-} \mathrm{b}-\mathrm{V}_{-} \mathrm{B}\right)^{\wedge}(-1)\right](\mathrm{b}-\mathrm{B}) \\
& =
\end{aligned} \\
& \begin{array}{rrr} 
& = & 26 . \overline{4} 4 \\
\text { Prob }>\text { chi2 } & = & 0.0004
\end{array}
\end{aligned}
$$

hausman y2 fe y2 re

Test: Ho: difference in coefficients not systematic

$$
\begin{aligned}
& \operatorname{chi2}(7)=(b-B) \cdot\left[\left(V_{-} b-V_{-} B\right) \wedge(-1)\right](b-B) \\
& \text { Prob }>\text { chi2 = } \quad 0.0000 \\
& \text { (V_b-V_B is not positive definite) }
\end{aligned}
$$

Fig. 4: Haussman test to compare fixed vs random effects panel regression

Source: Authors` own calculations in STATA 
The null hypothesis is the hypothesis that deviations can be viewed as random effects. The assessment is carried out on the basis of the p-level analysis, which for the models for $\mathrm{y} 1$ and $\mathrm{y} 2$, respectively, is:

Prob $>$ chi $2=0.0004$

Prob $>$ chi $2=0.0000$

Since in both cases the p-level is $<0.01$, the null hypothesis is rejected. Thus, a fixed effects model is better suited to describe the data of interest.

\subsection{Modeling}

To build models with fixed effects, we introduce dummy variables $\mathrm{d} 1 . . \mathrm{d} 28$, the coefficients of which will correspond to compensated spatial effects.

Let's consider the process of aggregating variables taking into account the panel data structure. To do this, we need to calculate the regression coefficients for a model containing dummy variables (Fig 5).

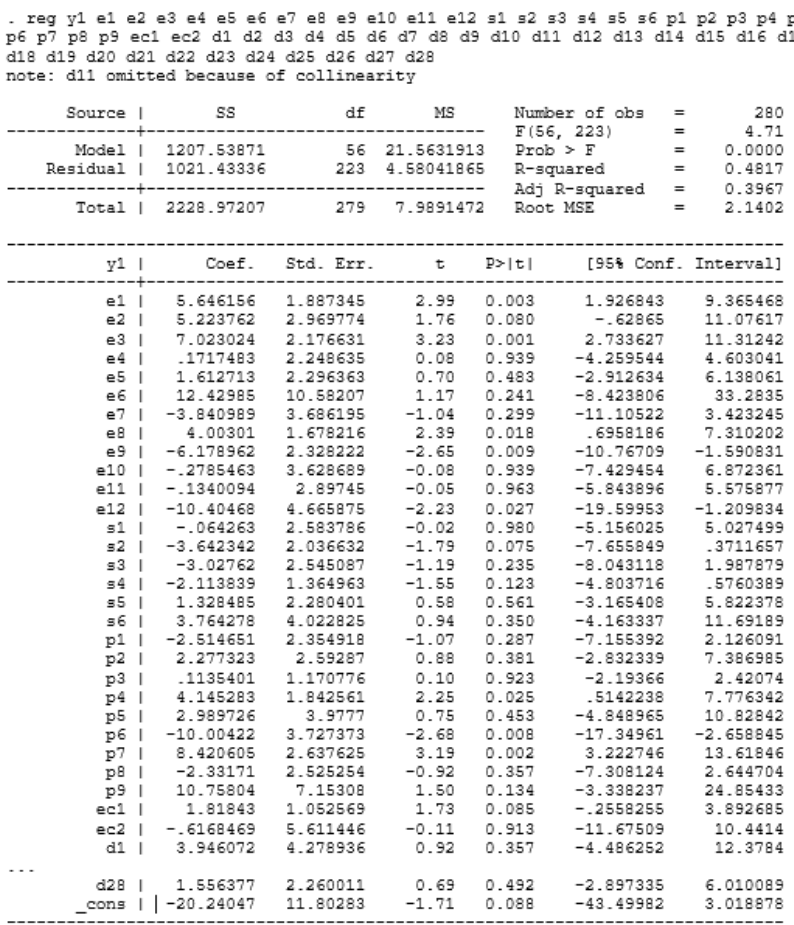

Fig. 5: Parameters of fixed effects panel regression model

\section{Source: Authors`own calculations in STATA}

Similarly, we are calculating the tables of regression coefficients for $\mathrm{y} 2, \mathrm{y} 1, \mathrm{y} 2$. This allows you to determine the direction of the connections of input and output variables, taking into account panel effects (Table 2).

As you can see from the Table 2, for some input variables, there is a difference between the direction of the relationship in the current and next year. Therefore, for further calculations, we will use only those indicators for which in table. 2, the same sign of connection with the output parameters $y 1, y 2$, $y 1 \_y 2_{-}$is observed. They form the following groups:

Economic positive:

- Infrastructure (e2).

- $\quad$ Product market (e3).

- $\quad$ Financial system (e5).

Economic negative:

- Innovation capability (e7).

- $\quad$ Economic decline (e9).

- $\quad$ Economic quality (e12).

Social positive:

- $\quad$ Health (s6).

Social negative:

- $\quad$ Social Globalization (s2).

- $\quad$ Refugees and IDPs (s4).

Political positive:

- $\quad$ Security apparatus (p4).

- $\quad$ Public services (p7).

- $\quad$ Governance (p9).

Political negative:

- $\quad$ Security (p1).

- $\quad$ External intervention (p6).

- Human rights \& rule of law (p8).

Environmental positive:

- $\quad$ Environmental performance (ec1).

Table 2. Connection of input and output variables, taking into account panel effects

\begin{tabular}{|c|c|c|c|c|c|c|}
\hline $\begin{array}{l}\text { Name of } \\
\text { variable }\end{array}$ & & & & & $\begin{array}{l}\text { Result } \\
y 1, y 2\end{array}$ & $\begin{array}{r}\text { Result } \\
y 1, y 2\end{array}$ \\
\hline & y1 & $\mathrm{y} 2$ & $\mathrm{y} 1$ & $\mathrm{y} 2$ & & \\
\hline e1 & + & + & - & - & + & - \\
\hline e2 & + & + & + & + & + & + \\
\hline e3 & + & + & + & + & + & + \\
\hline e4 & 0 & 0 & 0 & - & 0 & 0 \\
\hline e5 & + & + & + & + & + & + \\
\hline e6 & + & + & - & - & + & - \\
\hline e7 & - & - & - & - & - & - \\
\hline e8 & + & + & - & - & + & - \\
\hline e9 & - & - & - & - & - & - \\
\hline e10 & - & + & 0 & 0 & 0 & 0 \\
\hline e11 & - & - & + & + & - & + \\
\hline e12 & - & - & - & - & - & - \\
\hline s1 & - & 0 & + & + & - & + \\
\hline s2 & - & - & 0 & + & - & 0 \\
\hline s3 & - & - & - & - & - & - \\
\hline s4 & - & - & - & - & - & - \\
\hline s5 & + & 0 & - & - & + & - \\
\hline s6 & + & + & + & + & + & + \\
\hline p1 & - & - & - & - & - & - \\
\hline p2 & + & + & - & - & + & - \\
\hline p3 & 0 & + & - & - & 0 & - \\
\hline p4 & + & + & + & + & + & + \\
\hline p5 & + & + & - & - & + & - \\
\hline
\end{tabular}




\begin{tabular}{|c|c|c|c|c|c|c|}
\hline p6 & - & - & - & - & - & - \\
\hline p7 & + & + & + & + & + & + \\
\hline p8 & - & - & - & - & - & - \\
\hline p9 & + & + & + & + & + & + \\
\hline & & & & & & \\
\hline ec1 & + & + & + & + & + & + \\
\hline ec2 & 0 & 0 & + & + & 0 & + \\
\hline
\end{tabular}

Based on the table 2 and indicators listed above, we can recalculate the aggregation formulas taking into account panel effects (1).

$$
\begin{aligned}
& e 2 p=\overline{e 2, e 3, e 5} \\
& e 2 m=\overline{e 7, e 9, e 12} \\
& s 2 p=s 6 \\
& s 2 m=\overline{s 3, s 4} \\
& p 2 p=\overline{p 4, p 7, p 9} \\
& p 2 m=\overline{p 1, p 6, p 8} \\
& e c 2 p=e c 1
\end{aligned}
$$

Calculation of panel regression models using input variables formed according to formulas (1) made it

\begin{tabular}{|c|c|c|c|c|c|c|c|c|}
\hline Source & \multicolumn{2}{|l|}{ ss } & $d f$ & \multicolumn{2}{|c|}{ MS } & \multirow{4}{*}{$\begin{array}{l}\text { Number of obs } \\
\text { F (34, 217) } \\
\text { Prob > F } \\
\text { R-squared } \\
\text { Adj R-squared } \\
\text { Root MSE }\end{array}$} & \multirow{4}{*}{$\begin{array}{l}= \\
= \\
= \\
= \\
= \\
=\end{array}$} & \multirow{4}{*}{$\begin{array}{r}252 \\
6.78 \\
0.0000 \\
0.5653 \\
0.4791 \\
2.1197\end{array}$} \\
\hline & 1035.542 & & 34 & 30.4571 & 1439 & & & \\
\hline Residual & 974.970 & & & & & & & \\
\hline Total & 2010.513 & & 251 & 8.01001 & 1291 & & & \\
\hline $\mathrm{y}_{1}{ }_{-} \mathrm{I}$ & Coef. & Std. Err & & $t$ & $P>|t|$ & [95\% Conf. & Intervo & val] \\
\hline $\mathrm{e} 2 \mathrm{p}$ & 6.684165 & 4.498161 & & 1.49 & 0.139 & -2.181514 & 15.549 & 4984 \\
\hline & -12.83 & & & & & & -6.9738 & 3805 \\
\hline $32 p_{-}^{-}$ & 12.3232 & 3.791523 & & 3.25 & 0.001 & 4.85027 & 19.796 & \\
\hline$s 2 \mathrm{~m}_{-}^{-} \mid$ & -5.370959 & 2.851685 & & -1.88 & 0.061 & -10.9915 & .2495 & \\
\hline & 15.99989 & & & 4.48 & 0.0 & & 23.031 & \\
\hline & -11.27278 & 4.5 & & -2.46 & 0.015 & -20.30221 & -2.2433 & 3351 \\
\hline ec $2 p_{-}^{-} i$ & 5.297722 & 1.566837 & & 3.38 & 0.001 & 2.209554 & 8.385 & 8589 \\
\hline _cons i & -10.62124 & 3.802118 & & -2.79 & 0.006 & -18.11505 & -3.127 & 7433 \\
\hline Source & ss & & $d f$ & Ms & & & $=$ & \\
\hline & 1060.348 & & 34 & 31.186 & & $\begin{array}{l}\mathrm{F}(34,217) \\
\text { Prob > F }\end{array}$ & $\begin{array}{l}= \\
=\end{array}$ & $\begin{array}{r}7.05 \\
0.0000\end{array}$ \\
\hline Residual & 960.132 & & 217 & $4.4245^{\circ}$ & & & $=$ & 0.5799 \\
\hline Total & 2020.481 & & 251 & 8.04972 & 2536 & $\begin{array}{l}\text { Adj R-squared } \\
\text { Root MSE }\end{array}$ & $\begin{array}{l}= \\
=\end{array}$ & $\begin{array}{l}0.4803 \\
2.1035\end{array}$ \\
\hline$y^{2}-1$ & Coef. & Std. $\operatorname{Err}$ & & $t$ & $P>|t|$ & [95: Conf. & Interva & val] \\
\hline & & & & & & & & \\
\hline & & & & & & -2 & -9 & 199 \\
\hline $0^{-1}$ & $\begin{array}{l}11.915 \\
11.900\end{array}$ & $\begin{array}{l}3.78 \\
3.78\end{array}$ & & 3. & 0. & 4 & 19 & 15 \\
\hline & -6.766 & & & -2 & & -12 t & -1 & 78 \\
\hline & 15.33 & & & & & & & \\
\hline & -8.4750 & & & -1 & & & & \\
\hline ec $2 p_{-}^{-}$ & 5.505775 & 1.554869 & & 3.54 & 0.000 & 2.441196 & 8.5703 & 0355 \\
\hline $\begin{array}{c}\ldots . . . \\
\operatorname{con} s\end{array}$ & -9.008054 & 3.773076 & & -2.39 & 0.018 & -16.44462 & -1.571 & 1486 \\
\hline
\end{tabular}
possible to significantly improve their ability to explain dependencies in the data, expressed in terms of the coefficients of determination, in comparison with end-to-end regression models.

The calculation results (in a slightly reduced form) are shown in Fig. 6.

Fig. 6: Parameters of the aggregate fixed effects regression model

Source: Authors`own calculations in STATA
As we can see, the research results make it possible to explain up to $58 \%$ of the variations in the studied indicators.

Based on the results obtained (Fig. 6), it is possible to write down a general formula for calculating GDP growth in the next year, which will look like:

$$
\begin{aligned}
& y 1_{t+1}^{j}=-10.62+6.68 e p_{t}^{j}-12.83 e m_{t}^{j}+12.32 s p_{t}^{j}- \\
& -5.37 s m_{t}^{j}+16 p p_{t}^{j}-11.27 p m_{t}^{j}+5.3 e c 1_{t}^{j}+d 1^{j}
\end{aligned}
$$

where $d 1^{j}-$ coefficient of fixed effects

The general formula for calculating the growth of GDP per capita in the next year will be as follows:

$$
\begin{aligned}
& y 2_{t+1}^{j}=-9+5.49 e p_{t}^{j}-14.89 e m_{t}^{j}+11.92 s p_{t}^{j}- \\
& 6.77 s m_{t}^{j}+15.33 p p_{t}^{j}-8.47 p m_{t}^{j}+5.5 e c 1_{t}^{j}+d 2^{j}
\end{aligned}
$$

where $d 2^{j}$ - coefficient of fixed effects.

Formulas (2) and (3) can be used to analyze the economic security of countries in the short term and to predict their economic development.

Note that the signs of the coefficients for the aggregated variables in formulas (2) and (3) coincide with the directions of influence of the corresponding groups of factors, specified during aggregation (1).

Since the input data were normalized, the value of the coefficients for the aggregated variables can be interpreted as the strength of the influence of the corresponding aggregates on economic security. So, the most powerful are positive political factors (Security apparatus (p4), Public services (p7), Governance (p9)), as well as negative economic factors (Innovation capability (e7), Economic decline (e9), Economic quality (e12)). Also, great impact has such a social factor as the level of health of the population - Health (s6).

\section{Assessing the Effectiveness and Reliability of Results}

Authors think that the key in understanding the essence of the obtained results is the economic interpretation of the adjustment coefficients for dummy variables $\mathrm{d} 1 \ldots \mathrm{d} 28$. Let us consider it using the example of formula (3).

Authors calculate the formula (3) in parts (Table 3). 
Table 3. Average values of the components of formula (3) by countries

\begin{tabular}{|c|c|c|c|c|c|c|}
\hline \multirow[t]{2}{*}{ Country } & $\begin{array}{l}y 2_{t+1}^{j}- \\
d 2^{j}\end{array}$ & $d 2^{j}$ & $y 2_{t+1}^{j}$ & $\begin{array}{l}d 2^{j}- \\
y 2_{t+1}^{j}\end{array}$ & GDPpC & $\begin{array}{l}y 2 \\
\text { source }\end{array}$ \\
\hline & 1 & 2 & 3 & 4 & 5 & 6 \\
\hline Bulgaria & $-12,243$ & 15,684 & 3,442 & 27,927 & 5817 & 3,22 \\
\hline Romania & $-11,450$ & 15,814 & 4,364 & 27,264 & 7391 & 3,61 \\
\hline Latvia & $-7,871$ & 12,314 & 4,443 & 20,184 & 10613 & 3,69 \\
\hline Poland & $-5,865$ & 9,433 & 3,568 & 15,299 & 10911 & 3,65 \\
\hline Croatia & $-6,402$ & 8,328 & 1,926 & 14,731 & 10979 & 1,62 \\
\hline Hungary & $-8,845$ & 12,044 & 3,199 & 20,888 & 11195 & 3,05 \\
\hline Lithuania & $-7,622$ & 12,443 & 4,821 & 20,066 & 11515 & 4,86 \\
\hline Estonia & $-4,635$ & 8,566 & 3,931 & 13,201 & 13364 & 3,82 \\
\hline Slovakia & $-5,964$ & 8,543 & 2,579 & 14,507 & 14087 & 2,92 \\
\hline Czech Rep. & $-6,565$ & 8,651 & 2,086 & 15,217 & 16291 & 2,24 \\
\hline Portugal & $-4,791$ & 5,798 & 1,007 & 10,589 & 17023 & 1,11 \\
\hline Greece & $-5,700$ & 4,377 & $-1,323$ & 10,078 & 17461 & $-1,74$ \\
\hline Slovenia & $-3,001$ & 4,794 & 1,793 & 7,796 & 18465 & 1,67 \\
\hline Malta & $-4,534$ & 7,957 & 3,422 & 12,491 & 19122 & 3,47 \\
\hline Cyprus & $-2,180$ & 2,718 & 0,538 & 4,898 & 22387 & 0,51 \\
\hline Spain & $-5,450$ & 6,326 & 0,876 & 11,777 & 23332 & 0,88 \\
\hline Italy & $-7,305$ & 7,228 & $-0,077$ & 14,533 & 26278 & 0,15 \\
\hline UK & $-3,338$ & 4,339 & 1,001 & 7,676 & 31375 & 1,11 \\
\hline France & $-3,596$ & 4,215 & 0,619 & 7,811 & 31737 & 0,95 \\
\hline Germany & $-2,753$ & 3,963 & 1,209 & 6,716 & 34135 & 1,6 \\
\hline Belgium & $-4,433$ & 5,093 & 0,660 & 9,527 & 34311 & 0,95 \\
\hline Finland & 0,489 & 0,000 & 0,489 & $-0,489$ & 35528 & 0,88 \\
\hline Austria & $-1,325$ & 2,088 & 0,763 & 3,413 & 36592 & 0,93 \\
\hline Netherlands & $-0,955$ & 1,761 & 0,807 & 2,716 & 39548 & 0,95 \\
\hline Sweden & $-1,305$ & 2,305 & 1,000 & 3,610 & 41955 & 1,46 \\
\hline Ireland & $-1,966$ & 7,384 & 5,418 & 9,350 & 45856 & 5,39 \\
\hline Denmark & $-0,844$ & 2,355 & 1,511 & 3,199 & 45989 & 1,41 \\
\hline Luxembourg & $-3,259$ & 4,102 & 0,843 & 7,361 & 80707 & 0,85 \\
\hline
\end{tabular}

Source: Authors`own calculations

Column 1 of Table 3 shows the result of the calculations, excluding the adjustment factors. Column 2 contains the coefficients themselves. Column 3 is the total result of the formula calculations, and column 4 is the difference between columns 2 and 1 . The table is sorted by column 5 , which shows the absolute value of the per capita income level - GDPpC. The last column shows the average actual growth in per capita income.

Based on the principle of operation of the panel regression model with fixed effects, the coefficients for dummy variables $\mathrm{d} 1 \ldots \mathrm{d} 28$ show how much it is necessary to correct (increase or decrease) the result of model calculations for each object under study. For example, Bulgaria, Slovakia and Malta show approximately the same average GDPpC growth rates $(3.22,2.92$ and 3.5 , respectively). But at the same time, the value of the adjustment factors for Bulgaria is 15.155 on average, 8.751 for Slovakia, and 8.725 for Malta.

In other words, Bulgaria achieves the same rates of economic development with lower values of positive and higher values of negative indices of economic, social, political, environmental development than Slovakia and Malta.

Thus, it can be hypothesized that the adjustment coefficient shows the effectiveness of the country's economic development. The larger this coefficient, the less efforts the country needs to make to achieve high growth rates of per capita income. Let's check this hypothesis.

Let's plot the average GDPpC of the country and its corresponding value of the adjustment factor (Fig. $7)$.

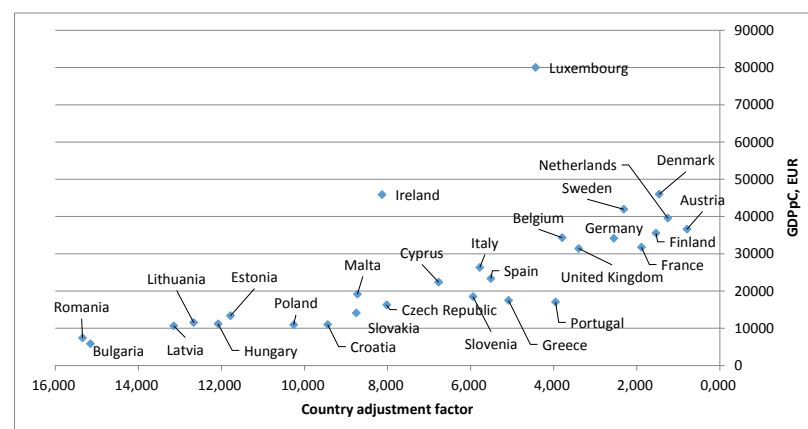

Fig. 7: Scatter plot of GDPpC level and country adjustment factor

Source: Authors`own calculations

As we can see from Fig. 7, despite the presence of several outliers, in general, there is a fairly strong relationship between the adjustment factors and the absolute value of GDPpC. It should be noted that this parameter was not used in the modeling, and therefore can be considered as independent. The calculated value of the correlation between the GDPpC values and the correction factors was 0.663 , and excluding Ireland and Luxembourg (which are located in Fig. 1 far from the main array of points and can be considered as statistical anomalies) was -0.849 .

Such a high value actually makes it possible to replace dummy variables and a set of coefficients for them in formula (3) with a logarithmic function (4), which is graphically shown in Fig. 8.

$d 2^{j}=-6.814 \ln \left(G D P p C^{j}\right)+74.129$

From functions (3) and (4), we obtained a model that is completely based on macroeconomic data and indicators of economic development.

The logarithmic nature is typical for the description of many economic patterns associated with the acceleration of growth rate or vice versa (Hutzler et al, 2021). Therefore, its application in the proposed model does not contradict empirical evidence.

Since the logarithmic function is nonlinear, and the panel regression models (2) and (3) are linear, it can be concluded that the adjustment coefficients account for nonlinear factors associated with the slowdown in economic growth in countries with high specific income levels. At the same time, it is 
these countries that have a higher level of economic stability.

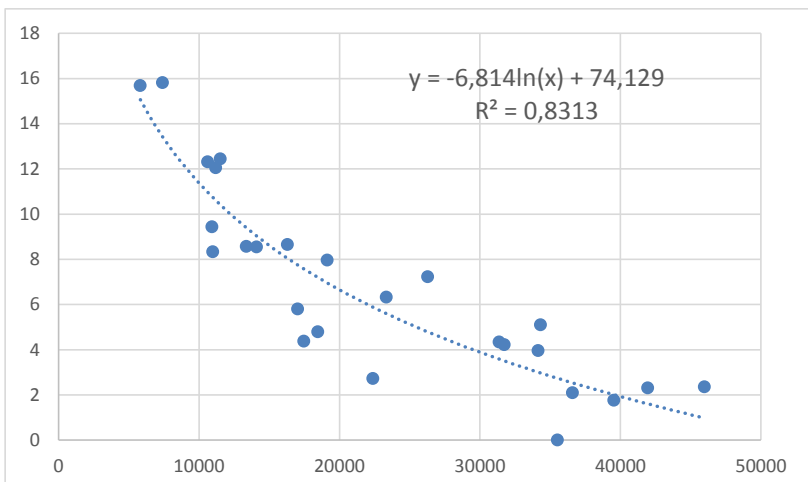

Fig. 8: Approximation the dependence of country adjustment factor on the GDPpC level by a logarithmic function

Source: Authors`own calculations

Thus, the integral indicator of economic sustainability can be obtained from models (2) and (3) by eliminating dummy variables. Authors consider the resulting indicator based on model (3), which is preferable, both in view of the higher value of the coefficient of determination, and from an economic point of view, since it provides the calculation of economic security in the future.

$$
\begin{aligned}
& e s_{t+1}^{j}=-9+5.49 e p_{t}^{j}-14.89 e m_{t}^{j}+11.92 s p_{t}^{j} \\
& -6.77 s m_{t}^{j}+15.33 p p_{t}^{j}-8.47 p m_{t}^{j}+5.5 e c 1_{t}^{j}
\end{aligned}
$$

Column 1 of Table 3 corresponds to the average values of the levels of economic security calculated by formula (5). As you can see, among the analyzed countries, Finland, Denmark, and the Netherlands have the highest level of economic security. And the lowest is Bulgaria and Romania, which does not contradict empirical data.

High values of adjustment factors are typical for countries with low per capita incomes. Therefore, it can be assumed that the higher the level of GDPpC, the more difficult it is to maintain sufficiently high rates of its growth. However, on the other hand, it may turn out that some of the baseline indicators are in fact not a cause, but a consequence of the country's high level of economic development, which allows investment in social and environmental development, as well as maintaining political stability. Since formal methods of correlation-regression analysis do not allow to reliably identify cause-and-effect relationships, this issue requires further study.

\section{Conclusion}

The research made it possible to propose and statistically substantiate formula (5) for calculating a composite indicator of the country's economic security. The indicator proposed by authors comprehensively characterizes the current state of the country's economic security in the economic, social, political and environmental spheres. This indicator makes it possible to determine the level and disproportions of the country's development and can become the basis for the formation of directions for ensuring its economic security.

Authors believe that there are no optimal values for the components of the proposed indicator of economic development that would be universal for all countries. Each country should strive to increase indicators that have a positive effect on economic development and to limit indicators that have a negative impact. Especially it is necessary to pay attention to the development of infrastructure, the internal market, the financial system, the health care system, the security apparatus, the level of public services and public administration. It is these factors, as shown by the study, are key in ensuring the economic security of the country.

The methodology of the article is based on statistical research methods, since they can be most fully documented in terms of assessing the reliability of the results. Further research can be directed towards identifying causal relationships between the level of economic security and individual subindicators of economic, social, political and environmental development. These relationships can be characterized by different strengths, lags, directions and other characteristics that have a strong influence on the development of policies in the field of ensuring the economic security of the country.

\section{References:}

[1] Ahlstrom, D., \& Bruton, G.D. (2010). International management. South-Western Cengage Learning, 2010. 504 p.

[2] Ziolo, M., Ben Ghoul, M. B., \& Aydın, H. İ. (2018). Financial Stability vs. Sustainable Development and Its Financing. In Sergi, B., Fidanoski, F., Ziolo, M., \& Naumovski, V. (Ed.), Regaining Global Stability After the Financial Crisis (pp. 88-107

[3] Lekar' S. I. (2012), "Foreign experience providing eco' nomic security, administrative and legal aspects", Visnyk Kharkivs'koho natsional'noho universytetu vnutrishnikh sprav, vol. 4 (2), pp. 103-111 
[4] Gryshova, I.; Kyzym, M.; Khaustova, V.; Korneev, V.; Kramarev, H. Assessment of the Industrial Structure and Its Influence on Sustainable Economic Development and Quality of Life of the Population of Different World Countries. Sustainability 2020, 12

[5] Hacker J.D.; Huber, G.; Rehm, P.; Schlesinger, M.; Valletta, R. (2014). Economic Security Index: A new measure for research and policy analysis. The Review of Income and Wealth, 60 (Suppl.), p. 5-32.

[6] Singer, J.D. The Correlates of War. Testing some Realpolitik Models; The Free Press: New York, NY, USA, 1980.

[7] Osberg, L. and Sharpe, A. (2014), Measuring Economic Insecurity in Rich and Poor Nations. Review of Income and Wealth, 60: S53-S76. https://doi.org/10.1111/roiw.12114

[8] Mourougane, Annabelle \& Roma, Moreno. (2003). Can Confidence Indicators be Useful to Predict Short Term Real GDP Growth? Applied Economics Letters. 10. 519-522. 10.1080/1350485032000100305.

[9] Helene Poirson, 1998. "Economic Security, Private Investment, and Growth in Developing Countries," IMF Working Papers 1998/004, International Monetary Fund.

[10] Retter, Lucia, Erik J. Frinking, Stijn Hoorens, Alice Lynch, Fook Nederveen, and William D. Phillips, Relationships between the economy and national security: Analysis and considerations for economic security policy in the Netherlands. Santa Monica, CA: RAND Corporation, 2020. https://www.rand.org/pubs/research_reports/R R4287.html.

[11] Moreira, Ricardo \& Zambon Monte, Edson. (2020). Reviewing monetary policy inertia and its effects: The fractional integration approach for an emerging economy. The Quarterly Review of Economics and Finance. 78. 10.1016/j.qref.2020.05.006.

[12] The Global Competitiveness Index. Available online: http://www3.weforum.org/

[13] Index of Economic Freedom. Available online: https://www.heritage.org

[14] The Fragile States Index. Available online: https://fragilestatesindex.org/

[15] KOF Index of Globalization. Available online: https://kof.ethz.ch/en/

[16] Human Development Index. Available online: http://hdr.undp.org/en

[17] World Bank. 2020. Doing Business 2020. Washington, DC: World Bank. DOI:10.1596/978-1-4648-1440-2
[18] The Democracy Index. Available online: https://www.eiu.com/

[19] Corruption Perceptions Index. Available online:

https://www.transparency.org/en/cpi/2019\#

[20] The Legatum Prosperity Index. Available online: https://li.com

[21] The Environmental Performance Index. Available online: https://epi.yale.edu

[22] El Gibari, S.; Gómez, T.; Ruiz, F. Building composite indicators using multicriteria methods: A review. J. Bus. Econ. 2019, 89

[23] Gan, X.; Fernandez, I.; Guo, J.; Wilson, M.; Zhao, Y.; Zhao, B.; Wu, J. When to use what: Methods for weighting and aggregating sustainability indicators. Ecol. Indic. 2017, 81

[24] Babenko, V., Gaponova, E., Nehrey, M., Ryzhikova, N., Zaporozhets, E. (2019). Life Expectancy of Population of the Country: The Role of Health Services Effectiveness. Research in World Economy, 10(4), pp. 8691. doi: https://doi.org/10.5430/rwe.v10n4p86

[25] Shumilo, O., Babenko, V., Liubokhynets, L., Volovelska, I., Arefieva, O. (2021). Method of Enterprise Economic Security Evaluation. Estudios de Economía Aplicada, 39 (7). https://doi.org/10.25115/eea.v39i7.4998

[26] Babenko, V.A., Koniaieva, Y.G. (2019). Determining priorities of scientific and technical cooperation between Ukraine, the EU and Chile in the field of non-conventional renewable energy sources. Acta Innovations (32), pp. 40-50. https://doi.org/10.32933/ActaInnovations.32.5

[27] Floridi, M.; Pagni, S.; Falorni, S.; Luzzati, T. An exercise in composite indicators construction: Assessing the sustainability of Italian regions. Ecol. Econ. 2011, 70

[28] Mazziotta, M.; Pareto, A. Methods for Constructing Composite Indices: One for All or All for One? Riv. Ital. di Econ. Demogr. Stat. 2013, LXVII, 67-80. Available online: https://www.istat.it/it/files/2013/12/Rivista201 3_Mazziotta_Pareto.pdf

[29] Hutzler Florian, Richlan Fabio, Leitner Michael Christian, Schuster Sarah, Braun Mario and Hawelka Stefan 2021 Anticipating trajectories of exponential growthR. Soc. open sci.8201574201574http://doi.org/10.1098/rsos .201574

[30] Euromoney, 2018. Methodology: Country Risk Ratings, The Handbook of Country and Political Risk Analysis. East Syracuse, NY: The PRS Group 
[31] Huber, G., Rehm, P., Schlesinger, M., \& Valletta, R. (2010). Economic Security at Risk: Findings from the Economic Security Index

[32] Moon, H., \& Weidner, M. (2017). DYNAMIC LINEAR PANEL REGRESSION MODELS WITH INTERACTIVE FIXED EFFECTS. Econometric Theory, 33(1), 158-195. doi:10.1017/S0266466615000328

[33] Huang, J., Wang, S., \& HUANG, J. Y. (2017). Empirical analysis of liquidity risk premium based on bond age. WSEAS Transactions on Business and Economics, 2224-2899.

[34] LY, T. D., DONG, P. X., Anh, L. H., \& An, P. T. H. (2020). The Effect of International Trade on Food Security at Southeast Asian Countries. WSEAS Transactions on Environment and Development, 16, 180-188.
Contribution of Individual Authors to the Creation of a Scientific Article (Ghostwriting Policy)

Olena Khadzhynova has designed the methodology. Žaneta Simanaviciene has created models.

Oleksiy Mints has carried out the econometrics modelling and implemented them on statistical data. Pavlo Burak and Valentyna Khachatrian have been responsible for the statistics.

\section{Sources of Funding for Research Presented in a Scientific Article or Scientific Article Itself}

This research is/was funded by the European Social Fund under the No 09.3.3-LMT-K-712-23-0211 "Transformation of the economic security system of enterprises in the process of digitalization" measure.

\section{Creative Commons Attribution License 4.0} (Attribution 4.0 International, CC BY 4.0)

This article is published under the terms of the Creative Commons Attribution License 4.0 https://creativecommons.org/licenses/by/4.0/deed.en US 